\title{
Novel enhancer for male fertility dysfunction in STZ diabetic rats
}

Muna Hasson Saoudi ${ }^{1}$, Mohammed A. Auda², Ahmed Adeeb Mohamed ${ }^{3}$

\section{Abstract}

This new study evaluated effect of aqueous leaves extracts of Chrozophora tinctoria (L.) Rafin on male reproductive hormones and histological features of the testis diabetic rats. The results obtained showed remarkable increased of sperm count, viability and motility after treatment. Testosterone, FSH and LH hormones also increased with oral administration of the plant extract at dose $70 \mathrm{mg} / \mathrm{kg}$ of body weight. The results suggested the anti-hyperglycemic property of the extract as well as its positive effect to maintain male hormones concentrations. Histological examination of the tests revealed improvement of spermatogenesis and Leydig cell proliferation with all doses of the extract. However, the histoarchitecture of the testis rats received 70 and 90 $\mathrm{mg} / \mathrm{kg}$ of the plant extract, was found to be similar to the healthy group. These findings suggest that the extract can maintain the damage fertility in diabetic rats. These promising results may explain the use of this plant in the future for therapeutic treatment of diabetes complications associated subfertility.

Keywords: Chrozophora tinctoria (L.) Rafin; Diabetes; Streptozotocin; Reproductive hormones; Hyperglycemia; Sperm

“Corresponding author email: munforever2004@gmail.com, munforever2004@mu.edu.iq

${ }^{1}$ Chemistry Department, College of Science, Al-Muthanna University, Samawah.

${ }^{2}$ Chemistry Department, College of Science, Thi-Qar University, Iraq

${ }^{3}$ College of Pharmacy, Al-Muthanna University, Samawah, Iraq.

Received October 01, 2021; revised November 30, 2021; accepted December 05, 2021; published December 19, 2021

Open-Access License: This is an open access article distributed under the terms of the Creative Commons

Attribution 4.0 International Public License (CC-BY 4.0), a copy of which is available at:

(https://creativecommons.org/licenses/by/4.0/legalcode). This license permits unrestricted use, distribution, and

reproduction in any medium, provided the original author and source are credited. $(\mathrm{cc}) \mathbf{E Y}$

\section{Introduction}

Diabetes mellitus is considered as the most common endocrine metabolic disorder [1] cause dysfunction in different tissues such as kidney, liver and testis, [2, 3]. Hyperglycemia as a result to diabetes is a significant underlying cause of a number of sexual disorders associated with complications of diabetes mellitus. More than $90 \%$ of diabetics suffered sexual complications recognized by infertility and low sexual activity [4]. Male reproductive functions can be reduced in diabetic's animals as well as humans $[5,6]$. Testosterone levels, sperm count and sperm 
motility also reduced in diabetics [7]. Many researchers reported that some plants have beneficial effects on enhancing fertility [8] and act as insulin regulator [9]. Furthermore, it has been reported that herbal plants have sperm DNA fragmentation induction [10] and reproductive regulatory effects with low toxicity like infertility stress-induced [11]. Presently, studies interested in developing a regulator of male reproductive function which is both effective and safe, with highly sperm generation via non-hormonal and hormonal essays [12]. There are no proofs of ant hyperglycemic effects of these herbal plants [13].

Chrozophora tinctoria (L.) Rafin which grows in deep soils and sandy plains in Al-Salman desert in Al-Muthanna governorate, south of Iraq, belongs to Euphorbiaceae family. It is well established that this plant was used for colouring Dutch cheese and certain liquors. Commonly it is used for the remedy of warts [14]. It was also used as an emetic, cathartic, and for the treatment of fever [1]. On the other hand, analysis of Chrozophora tinctoria (L.) Rafin showed that it contained flavonoids, alkaloids, diterpenoids, xanthones, coumarins, chromones, diterpenoids, and phenyl propanoid glycosides $[15,16]$. This work is a first study to evaluate the effect of oral administration of aqueous extracts of leaves of Chrozophora tinctoria (L.) Rafin aqueous on selected fertility hormones (testosterone, follicle stimulating hormone FSH and leutinizing hormone $\mathrm{LH}$ ) and its effects on sperm parameters male diabetic rats. To the best of our knowledge, this study is the first report on the effects of the Chrozophora tinctoria (L.) Rafin aqueous extract on male fertility and this will verify its benefit and positive effect to find out its therapeutic component for a reproductive disorder.

\section{Materials and Methods}

Collection and Authentication of Plant

The herbal plant was collected during the period of May to September (2017) from the Al-Salman desert which is located in Al-Muthanna governorate, south of Iraq, about $200 \mathrm{~km}$ (124 miles) south of Samawah city. The plant has been identified by botanical Prof. Dr. Taha Yaseen Mhoder Al-Edany (Plant Taxonomy and Ecology, College of Agriculture, University of Basrah, Iraq).

\section{Aqueous Extract}

Fresh leaves of Chrozophora tinctoria (L.) Rafin were dried in the shade for two weeks and then $250 \mathrm{~g}$ collected separately. The leaves were crushed gently to powder. In $2.0 \mathrm{~L}$ of sterile distilled water the powder was suspended for 24 hours at $50 \stackrel{\circ}{ } \mathrm{C}$ [17]. The resulting solution was filtered and stored for the rats pharmacological study [18]. 


\section{Animal Models}

The male rats were purchased from Biotechnology Research Center of AL-Nahrain University, Iraq. The rats have 90 days of age and $220 \pm 10 \mathrm{~g}$ of weight. The rats maintained in a $12 \mathrm{~h}$ for both light and dark cycles at $27^{\circ} \mathrm{C}$ during the study in the animal house. The roles of National Institutes of Health policy were followed for animal care during the experiment. Control and treated rats were received food and water ad libitum.

Diabetic Model rats and treatment

The male rats intraperitoneal injected by a single dose of $55 \mathrm{mg} / \mathrm{kg}$ BW STZ (Sigma-Aldrich) that dissolved in saline solution [19]. The normal control group of rats received an equivalent amount of saline solution. After two days of injection and by (using the glucometer ACCU-Check, Roche Diagnostics Corporation, USA), the levels of fasting blood glucose were checked. The rats were considered diabetic with fasting blood glucose over $11 \mathrm{mmol} / \mathrm{L}$ [20]. Extract Chrozophora tinctoria (L.) Rafin solution was administrated with different selected doses as daily drink. The doses were daily prepared in order to avoid oxidation and rancidity and unconsumed food over $24 \mathrm{~h}$. Animals used as normal control received standard rat pellet with ad libitum, distilled water till the end of the experiment.

\section{Animals Experimental Design}

Twenty-five male rats were randomly divided into five groups and placed in cages according to the groups, containing 5 rats per group. Group I, considered as the normal control, given standard food and water for a period of 35 days; Group II, served as the diabetic control, given Streptozotocin $55 \mathrm{mg} / \mathrm{kg}$ b.w. as a single dose; Group III, received Streptozotocin (55 mg/kg b.w.) and given leaves aqueous extract of Chrozophora tinctoria (L.) Rafin $50 \mathrm{mg} / \mathrm{kg}$ b.w. administrated orally every day for a period of 35 days); Group IV, received Streptozotocin (55mg/kg b.w.) and given leaves aqueous extract of Chrozophora tinctoria (L.) Rafin $70 \mathrm{mg} / \mathrm{kg}$ b.w. administrated orally every day for a period of 35 days. Group V, received Streptozotocin ( $55 \mathrm{mg} / \mathrm{kg} \mathrm{b.w.)} \mathrm{and}$ given leaves aqueous extract of Chrozophora tinctoria (L.) Rafin $90 \mathrm{mg} / \mathrm{kg}$ b.w administrated orally every day for a period of 35 followed by receiving standard food and water for diabetic control and the treated diabetic rats. After 35 days, the rats were fasted for 12 hours and sacrificed by inhalation mild diethyl ether. Blood samples were obtained by means of heart puncture, serum was separated and stored for male sexual hormone determination, testis tissues were collected for histological study. 
Blood sampling and biochemical analyses

At the end of experiment, blood samples were collected from the heart using five milliliters syringes and left to clot for separating the serum after centrifugation at $3000 \mathrm{rpm}$ for 15 minutes. Serum samples were directly frozen at $-10{ }^{\circ} \mathrm{C}$ till biochemical analyses. Testosterone concentration, FSH and LH were determined using VIDAS kits with the ELFA Tanique (Enzyme Linked Fluorescent Assay).

Microscopical examination

Spermatozoa had been assessed according to WHO laboratory manual [21] for sperm parameters, viability, percentage dead spermatozoa, motility and abnormalities.

Histological Examinations

The perfuse-fixed testes settled in Bouin fluid overnight, and prepared for normal paraffin lodging. The testis was grooved into $5.0 \mu \mathrm{m}$ sections. Three successive sections per testes were placed on slides, deparaffinized, rehydrated, and stained with hematoxylin - eosin stain.

Statistical analysis

The results were expressed using One-way ANOVA and Newman-Keuls Multiple Comparison Test, $N=5$, NS (NON SIGNIFICANT) ${ }^{*} \mathrm{P}<0.05,{ }^{* *} \mathrm{P}<0.01$, and ${ }^{* *} \mathrm{P}<0.001$.

\section{Results}

Sperm count, viability, motility and abnormal sperm

The sperm quality which involved sperm count and the normal sperm count, number of dead sperms were determined and significantly reduced in the non-treated diabetic group in comparison to the control non treated group. These results were remarkable reversed in the administration of different doses $(50,70,90 \mathrm{mg} / \mathrm{kg})$ to experimental groups. It was observed that aqueous Chrozophora tinctoria (L.) Rafin treatment groups showed a significant rise in sperm motility and viability in addition to the sperm count when compared to the diabetic group. While the treated rats with $90 \mathrm{mg} / \mathrm{kg} \mathrm{B.W}$. showed significant increasing in sperm count and motility as indicated in Figure 1. Similarly, the number of abnormal sperms and percentage of dead lowered greatly with the treatment of the aqueous extract as shown in. (Figure 2, and 3) respectively. 


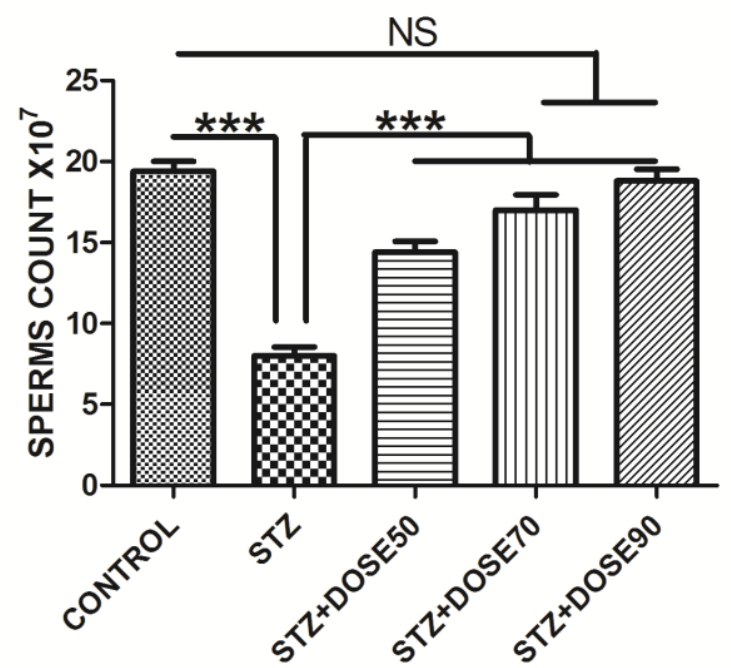

Figure 1.

Shows effect of aqueous leaves Chrozophora tinctoria (L.) Rafin extract on sperms count of control and various experimental groups.

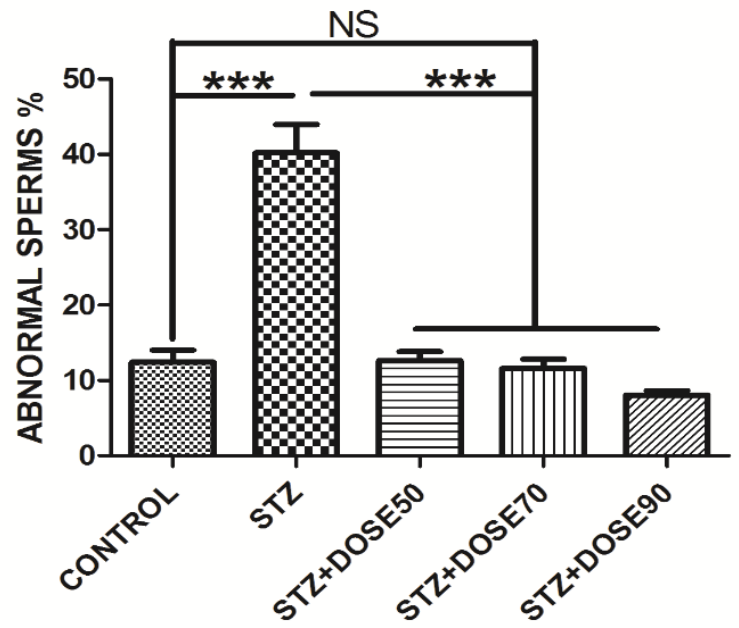

Figure 2.

Shows the effect of aqueous leaves Chrozophora tinctoria (L.) Rafin extract on percentage of abnormal sperms of control and various experimental groups. 
Figure 3.

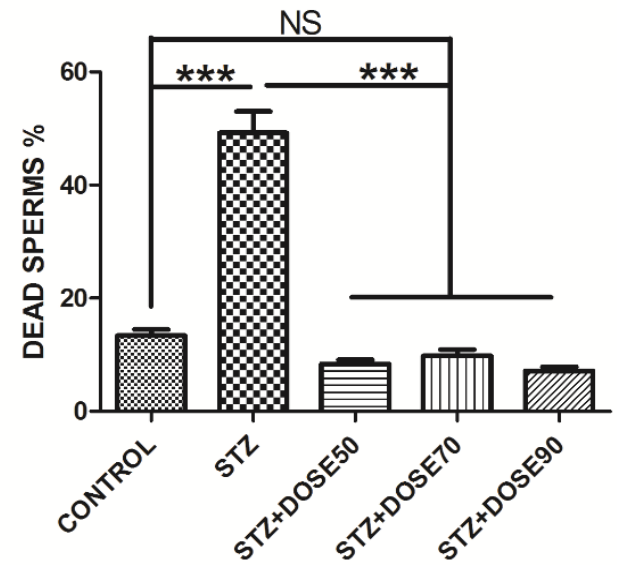

Shows the effect of aqueous leaves Chrozophora tinctoria (L.) Rafin extract on percentage of dead sperms of control and various experimental groups.

Hormonal analyses

The study indicated a significant decrease of all serum male hormone levels in the non-treated group when compared with the healthy group. The aqueous extract with $90 \mathrm{mg} / \mathrm{kg}$ was able to maintain the reduction of the serum testosterone to a good value (Figure 4). Similarly, both FSH and LH levels were also maintained with the administration of the extract at three doses (Figure 5 , and 6) respectively. There was a noticeable increase in the hormone levels compared to untreated group.

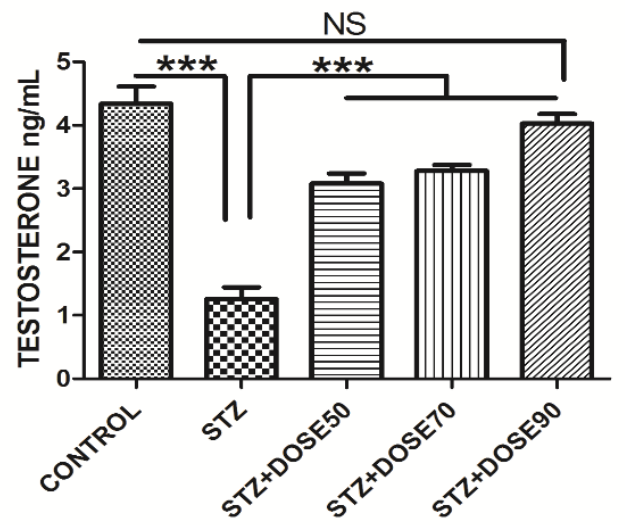

\section{Figure 4.}

Shows the effect of aqueous leaves Chrozophora tinctoria (L.) Rafin on testosterone levels of control and various experimental groups. 


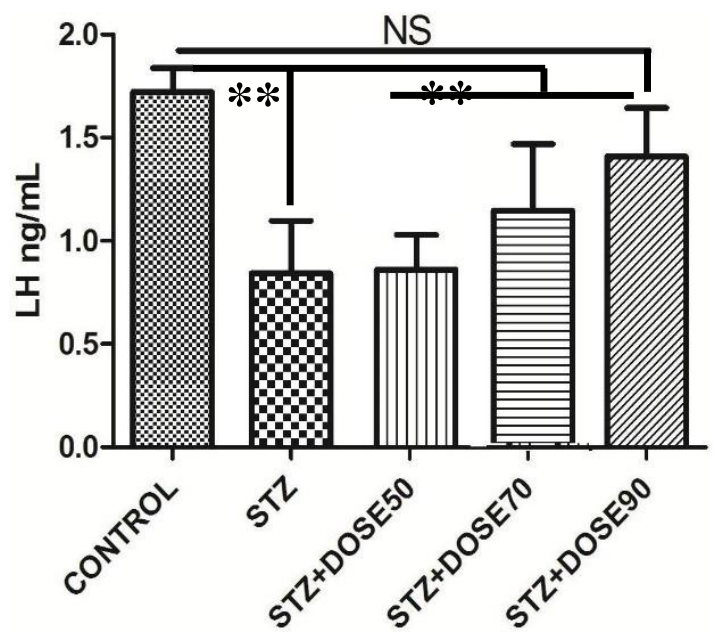

Figure 5.

Shows the effect of aqueous leaves Chrozophora tinctoria (L.) Rafin on LH levels of control and various experimental groups.

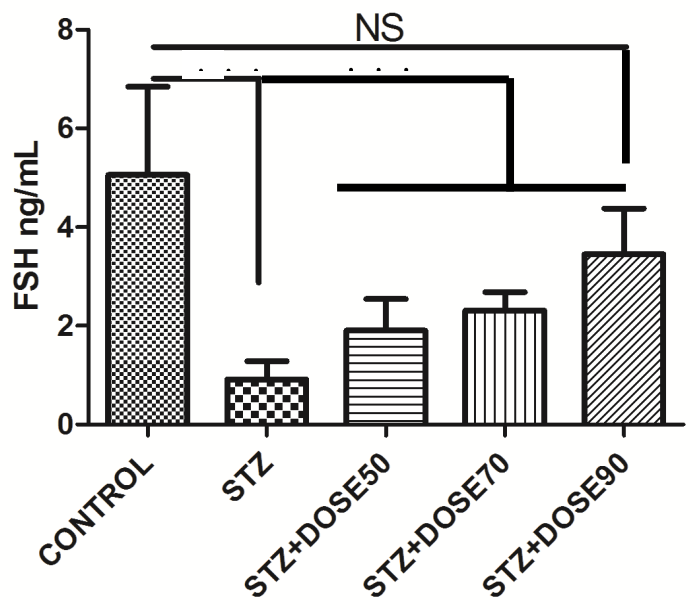

Figure 6.

Shows the effect of aqueous leaves Chrozophora tinctoria (L.) Rafin on FSH levels of control and various experimental groups. 


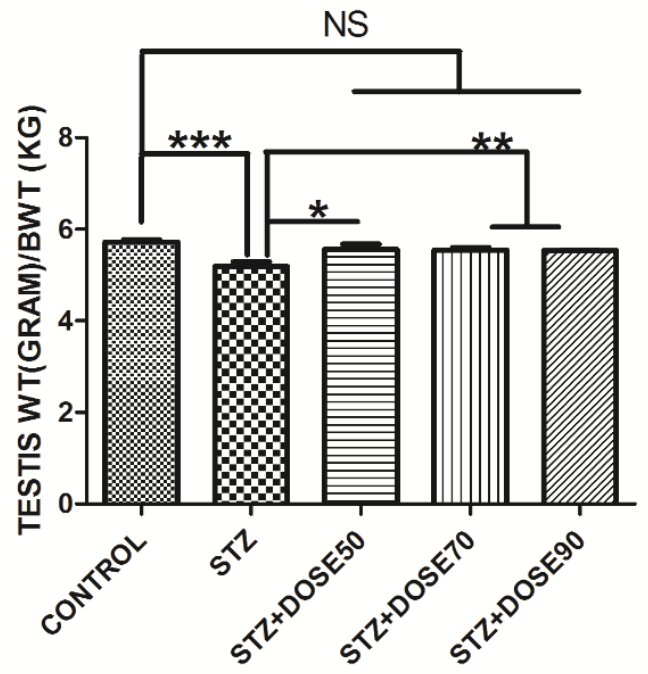

Figure 7.

Shows the effect of aqueous leaves Chrozophora tinctoria (L.) Rafin on testis weight of control and various experimental groups.

Glucose levels, insulin levels and changes in testis weight

Previous report has established anti hyperglycemic and hepatoprotactive effect of aqueous extract of Chrozophora tinctoria (L.) Rafin Lin STZ diabetic rats [22, 23]. Earlier findings indicate the maintenance of glucose, insulin and liver enzymes to near normal values in all treated groups as supported by histological results of hepatic tissues which are in agreement with the obtained data. Furthermore, it was demonstrated that the extract can effectively manage all the destruction of hepatic cells caused by STZ. Moreover, the extract showed no toxicity till $955 \mathrm{mg} / \mathrm{kg}$ in the acute toxic study [22]. The present study was designed to investigate the potent of the target extract on male reproductive function in male diabetes was investigated. The results showed that testis weight with aqueous extract treated group was found to be slightly elevated along with the treatment of the aqueous extract in different doses compared to diabetic group. The supplementation of Chrozophora tinctoria (L.) Rafin extract with $50 \mathrm{mg} / \mathrm{kg} 70 \mathrm{mg} / \mathrm{kg}$ and $90 \mathrm{mg} / \mathrm{kg}$ of aqueous extract increase in the testis weight when compared with negative control group. Furthermore, there was no difference in the weight of the testis in group treated with $90 \mathrm{mg} / \mathrm{kg}$ when compared to healthy group as indicated in Figure 7. 


\section{Histopathological examinations}

Testicular histopathological changes in all groups were observed. Control rats section testis showed normal wall of seminiferous tubules, regular germinal epithelia with prominent basement, apical portion of sertoli connected with large number of spermatognia, leydig cells have prominent nuclei which aggregations as cluster between seminiferous tubules. The sertoli cells have normal triangular shape filled with normal spermatogenic cells in different stages of spermatogenias as indicated in Figure 8, and 9, while in the STZ diabetic group, the shape of seminiferous tubules was ubnormal with partial distribution in the wall of seminiferous tubules.as well as acute distribution in germinal epithelia. The current result of testis noted abnormal sertoli cells.

All tissue sections noted completely disappeared of spermatid from S.T. (Figure10). Compared with diabetic group, the testis section of group treated with $50 \mathrm{mg} / \mathrm{kg}$ BW showed more proliferation of germinal epithelia in some of seminiferous tubules. The sertoli cells have spermatogonia cells in different stages of spermatogensis (Figure11). In the extract treated groups with70mg/kg B.W, the histological results showed high proliferation of leydig cells between the somniferous tubules. It was observed that leydig cells have triangular shape with prominent nuclei. Seminferous tubules also have normal structure and contain high aggregation of normal spermatogenic cells in different development stages with wide lumen.

The spermatids were aggregation as cellular mass in the center of lumen. All sections of somniferous tubules have very prominent B.M. with prominent germinal epithelia, the sertoli cells have development spermatogenic cells in different stages. All tissue sections of testis noted no blood congestion between S.T., and large aggregation of leydig cells as shown in Figure12. Whearse, the section of the rats treated with $90 \mathrm{mg} / \mathrm{kg}$ BW showed somniferous tubules with normal walls and germinal epithelia compared with control healthy group, normal sertoli cells which have different stages of spermatogonic cells.

The present results showed active germinal epithelia belong the inner surface of somniferous tubules with prominent B.M. The histological results showed some of spermatogonic cells in early stage aggregation as small clusters near the basal portion of sertoli cells. The tissue section of testis showed all S.T. have cytoplasmic fragments in their lumen.

The histological changes in the testis after treated with 90 have high concentration of extract lead to these histological changes in the seminiferous tubules Figure 13. 


\section{American Journal of BioMedicine \\ AJBM 2021;9(2):189-206}

\section{Research Article doi: 10.18081/2333-5106/9.4/190}

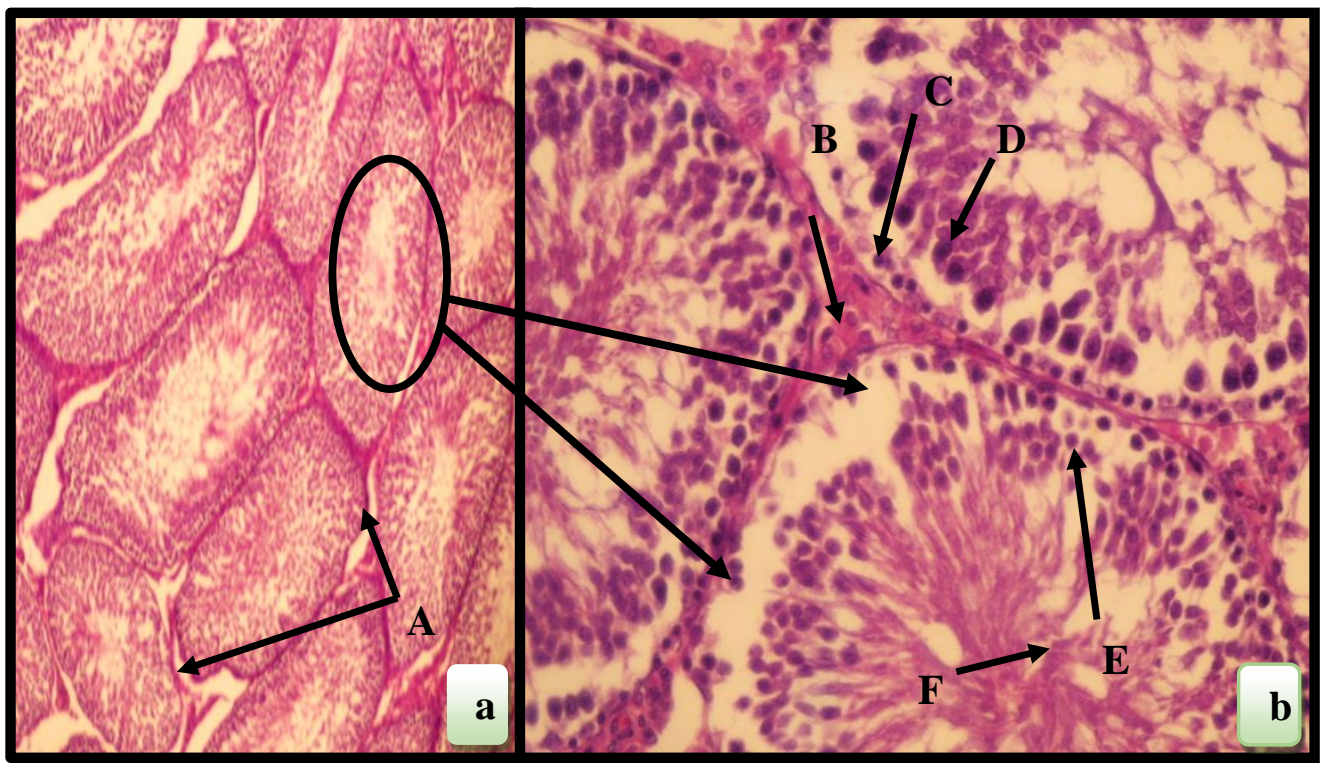

Figure 8.

Photograph of testis in control Rat showed:

Basement membrane (A), Seminiferous tubule (black cycle), Leydig cell (B), Spermatogonia (C), Primary spermatocyte (D), Secondary spermatocyte (E), Spermatid (F). (H \& E) 100X (a) and 400X (b).

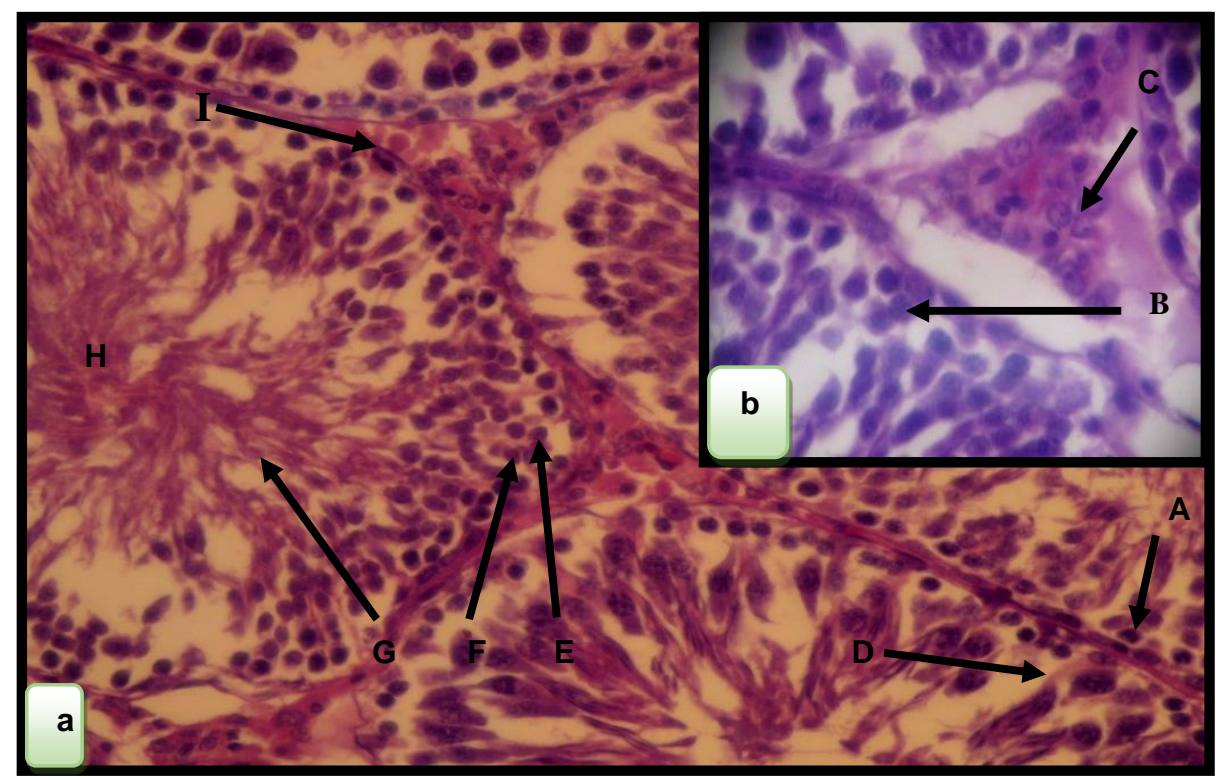

Figure 9.

Photograph of testis in control Rat showed: Spermatogonia A. (A), Spermatogonia B. (B), Leydig cell (C), Sertoli cell (D), Primary spermatocyte (E), Secondary spermatocyte (F), Spermatid (G), Myoepithelial cell (I). H \& E 200X (a) PAS 400X (b). 


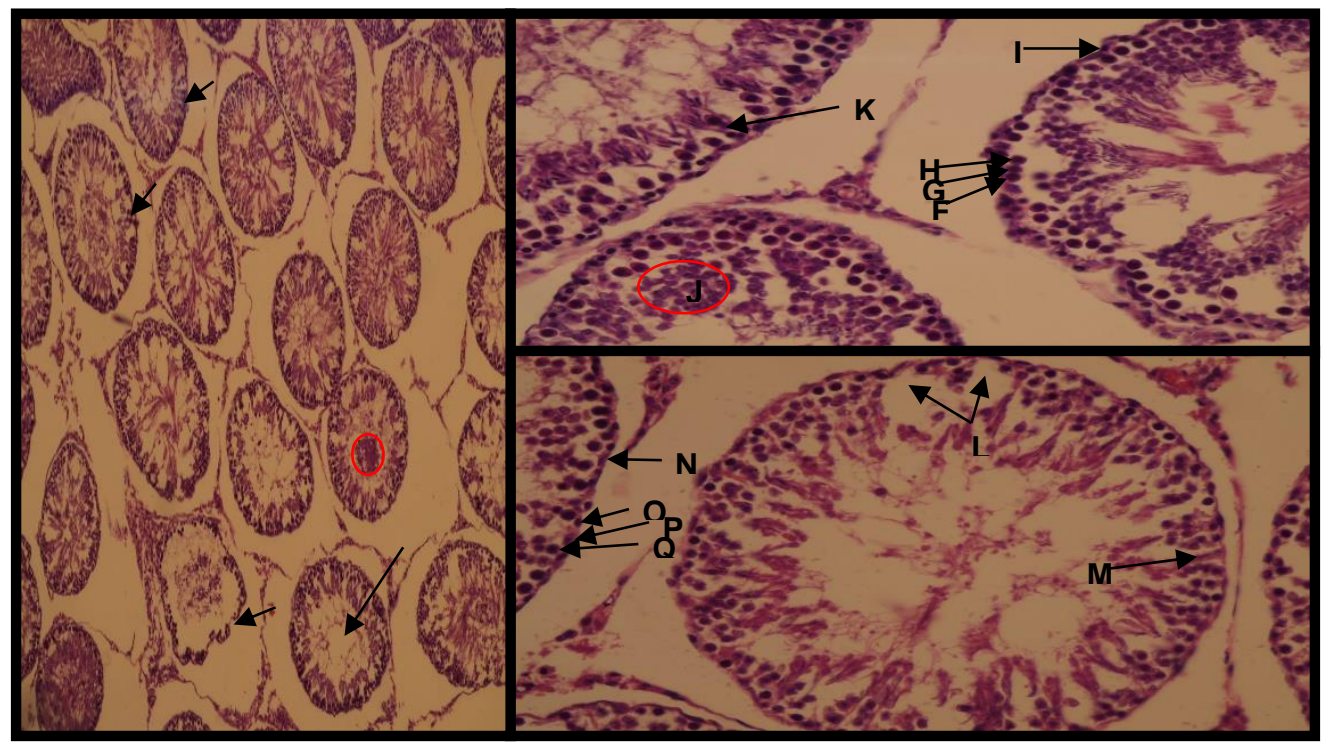

\section{Figure 10.}

Photograph of testis in STZ Rats showed: H \& E 100X (a) 400X (b),(c). A: Acute distruction in wall; B: Abnormal germinal epithelia; C: Progressive spermatogenic cells; D: Spermatogonia; E: Lumen; F: Spermatogonia A.; G: Spermatogonia I.; H: Spermatogonia B.; I: Basement membrane; J: Proliferation of germinal epithelium; K: Sertoli cells; L: No germinal epithelia; M: Abnormal sertoli cells; N: Basement membrane; O: Spermatogonia A.; P: Spermatogonia I.; Q: Spermatogonia B.; R: Spermatogenic cells in different stage.

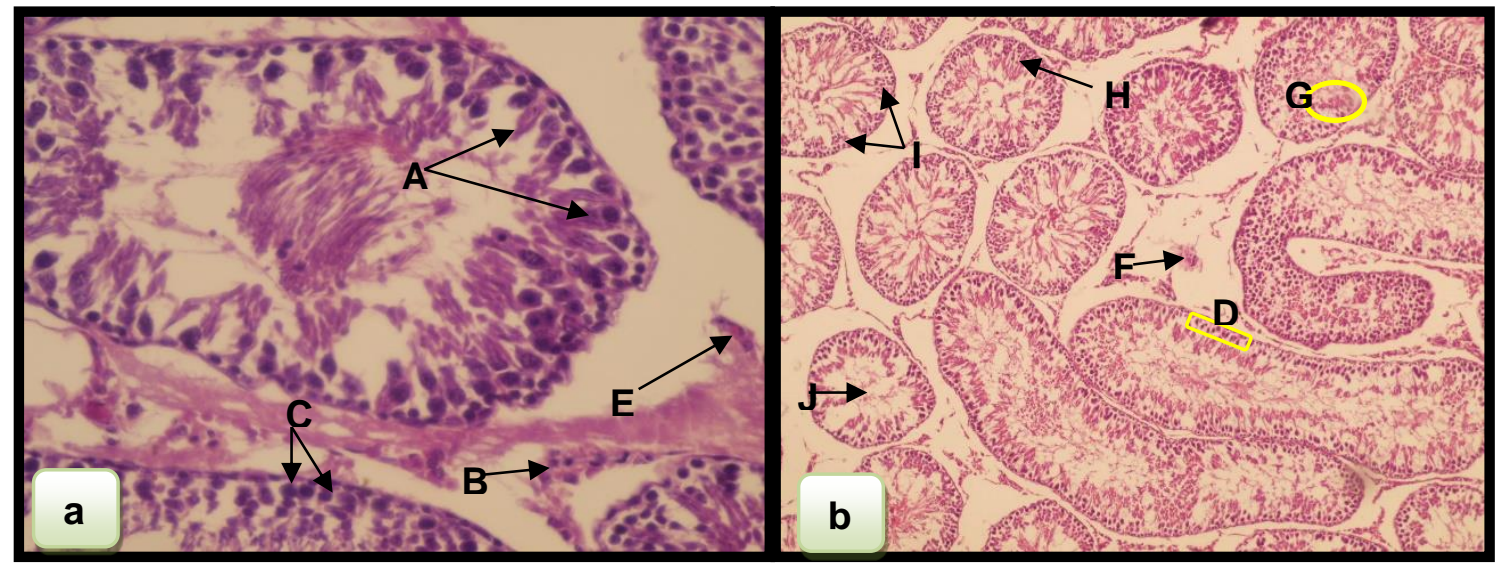

\section{Figure 11.}

Photograph of testis in STZ Diabetic Rat liver treated with $50 \mathrm{mg} / \mathrm{kg}$ showed: A: Sertoli cells; B: Leydig cells; C: Germinal epithelia; D: Spermatogonia; E: Blood vessels; F: Leydig cells; G: Aggregation of spermatogenic cells; H: Sertoli cells; I: Normal sertoli cells; J: Lumen. H \& E 100X (a) and 400X (b). 


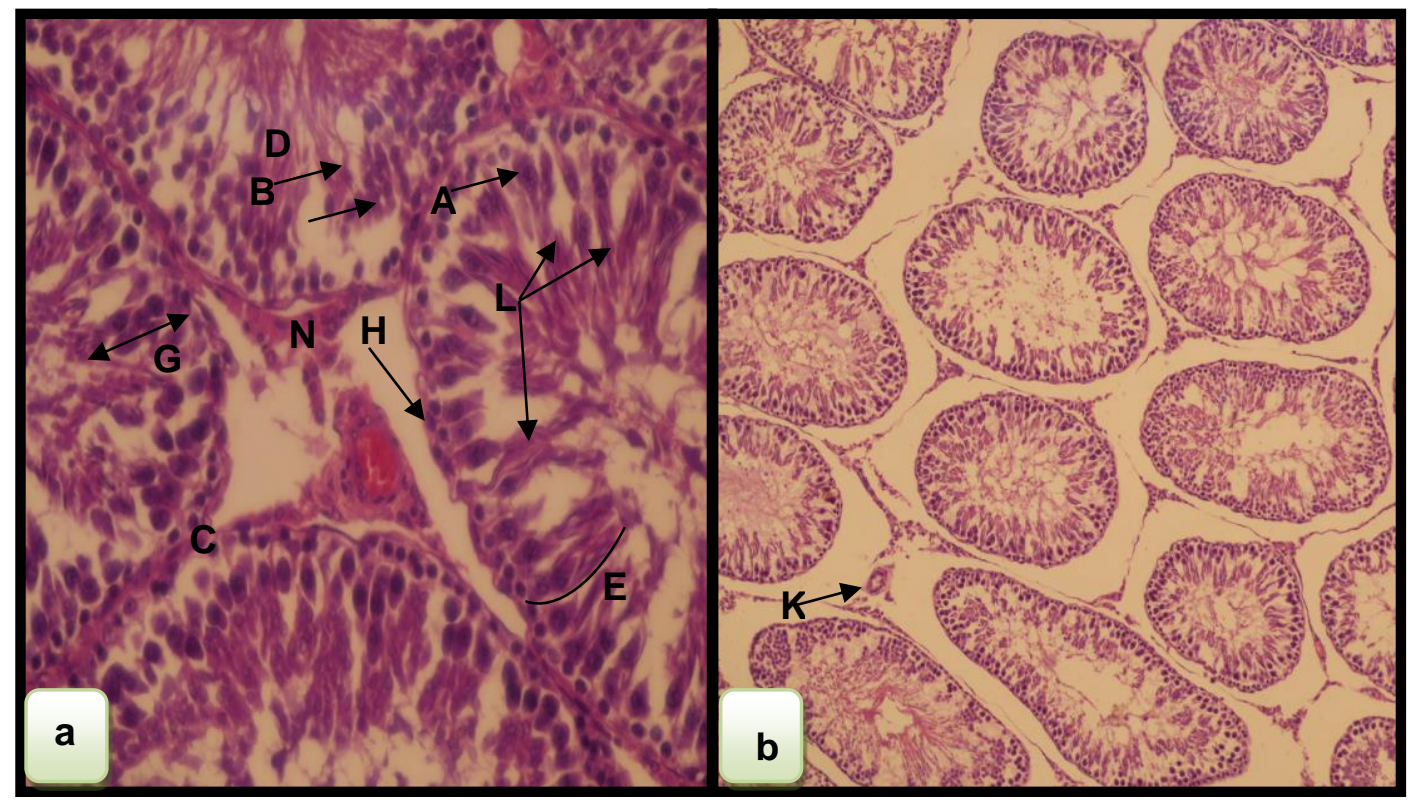

\section{Figure 12.}

Photograph of testis in STZ Diabetic Rat liver treated with $70 \mathrm{mg} / \mathrm{kg}$ showed: A: Sertoli cells; B: Spermatid; C: Wall S.T.; D: Prominent Basement membrane; E: Normal limit sertoli; G: development spermatogenic cells; H: prominent B.M.; K: blood vessels; N: aggregation of leydig cells; L: high proliferation of spermatid. H \& E 400X (a) and 100X (b).

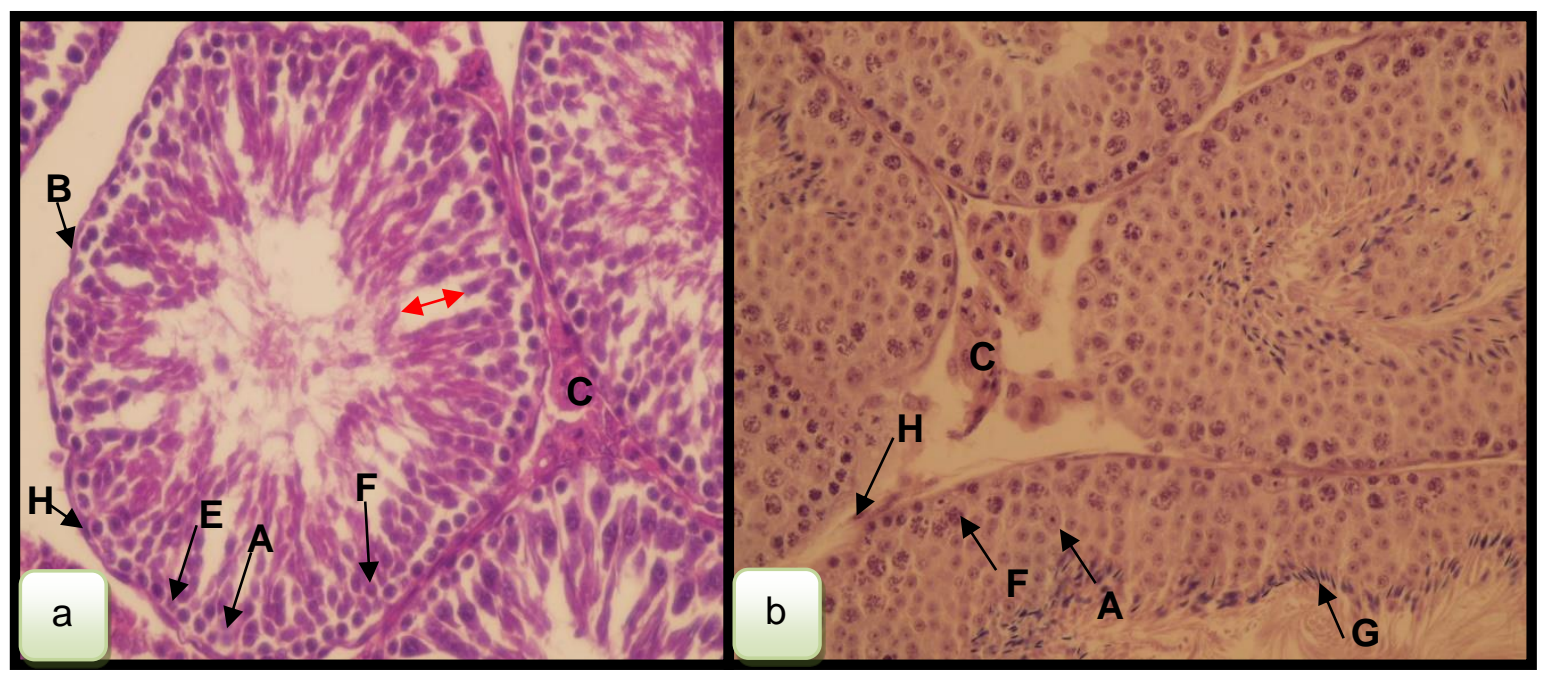

Figure 13.

Photograph of testis in STZ Diabetic Rat liver treated with $90 \mathrm{mg} / \mathrm{kg}$ showed: A: sertoli cells; B: wall of S.T.; C: Leydig cell; E: spermatogonia I; F: Primary spermatocyte; G: Spermatid; H: Myoepithelial cell; :sertoli cell. H \& E 200X (a) PAS 400X (b 


\section{Discussion}

The current study reveals the potency of aqueous Chrozophora tinctoria (L.) Rafin extract as enhancer of fertility in streptozotocin diabetic male rats. STZ caused dysfunction of male fertility function and resulted in a decrease of blood testosterone levels in diabetic rats in contrast with healthy normal rats [24]. Whereas some other studies reported, there is no change in blood testosterone levels in such rats $[25,26]$. In our study, the mean blood testosterone level in untreated diabetic rats reduced in evaluation with healthy rats. However, there is an improvement in testosterone levels in all treated groups.

The dose of 90 showed highly enhancement of Testosterone level to similar normal values. The findings of this study also revealed that the mean blood level of follicle-stimulating hormone (FSH) and luteinizing hormone (LH) in diabetic rats showed a significant reduction in contrast to control healthy rats. Moreover, the treated groups indicated an increase of those hormone levels when compared to untreated group. The possible cause of sexual hormones dysfunction is the absence of insulin in STZ induced diabetic rats can alter, regulate and modify the serum FSH levels [27]. The reduced level of FSH can cause cell self-destruction in productive cells that have testosterone receptors [28], but this is not the only factor for this dysfunction because diabetes also induces a reduction of blood LH levels [29,30] since insulin has the main role for the normal function of the maintenance of LH receptors on Leydig cells in controlling cell proliferation [31].

Those findings indicate the vital function of insulin and glucose in the regulation of the pituitary glands function in synthesis and releasing of FSH and LH subsequently, for normal functions of gonads in the management of sexual hormones. The Supplementation of the plant extract at different doses $(50,70$ and $90 \mathrm{mg} / \mathrm{kg}$ ) has a clear recovery in T, FSH and LH levels. The results markedly demonstrate the efficacy of the aqueous extract to maintain sexual hormones in diabetic animals.

It is well known that inducing DM by injection rats with STZ have toxic effects on testicle and linked to alterations in sperm morphology of induced animals. DM is associated with a rise in oxidative stress, which damage sperm nuclear and mitochondrial DNA [32]. The current study showed a reduction in sperm count and motility which was more observed in untreated diabetic group with poorly damage to the testicular epithelium that recognized in histopathological sections. In contrast, the oral administration of the aqueous extract to the STZ diabetic rats had reduced STZ mediated changes in the sperm shape abnormities and improved testicular activities suggesting its protective potential against spermatotoxic and testicular toxicity in 
diabetic. The damage in testicular epithelium, as well as the decrease in sperm quality was normalized highly in group treated with $90 \mathrm{mg} / \mathrm{kg}$. The results indicate the spermatogenic potency of the extract. Furthermore, there is a relationship between diabetes and male subfertility defective [33], because the cytoplasmatic carbohydrates (mostly glucose) are the trail motive to supply sufficient energy to the most of biochemical activities such as mitosis and miosis. Any interruption in glucogenic pathway through germinal epithelium is able to impact their division and biological activities, which in turn can activate spermatogenesis detention in seminiferous tubules [34, 35].

Histopathological changes revealed marked decline of most seminiferous tubules include endocrine disorders [31]. These effects may be due to reduction of serum testosterone levels [36]. Oral administration of the plant extract to the diabetic rats at period of study 35 days, caused enhancement of the histological changes of both testis and epididymis. These results indicate that used target extract acts to attenuate the degenerative changes in testes and epididyms because it contains many compounds act to enhance testis function and retards to normal state. The presence of these phytochemical compounds such as saponin, flavones, tannins and terpenes and due to their antioxidant activities reduce or prevent generation of free radicals which alter male fertility.

Another possible reason for the enhancement in cell proliferation and spermatogenesis in the rat treated testis may be due to maintaining insulin level [37] which associated with regulating gonadotropin releasing hormones $\mathrm{GnRH}$ secretion [31]. Sertoli cells dysfunction in turn could be able to result in germinal cells degeneration and dissociation [38]. Many studies indicated the metabolic alteration in these cells derived from DM may be responsible for spermatogenesis disruption associated with this pathology, because Sertoli cells have a glucose sensing machinery that reacts to hormonal variations to neutralize hyper and hypoglycemic effect [39]. It was demonstrated that improvement of sertoli cells which occurred due to consumption of the extract has a positive role on male androgenic activity. Hence, from the present study and the previous report, it was concluded that aqueous extract of Chrozophora tinctoria is not just revealed to be a future sexual enhancer, but is also considering androgenic, spermatogenic and antidiabetic in STZ-induced diabetic rats.

\section{Conclusions}

In this new study, aqueous Chrozophora tinctoria (L.) Rafin extract has demonstrated to enhance diabetic male fertility and caused positive changes in the production of the male sex cells as well as confirmed its property as anti-hyperglycemic potential. Aqueous Chrozophora tinctoria (L.) Rafin extract suggested as natural product to treat diabetic effectively from infertility 
by increasing sex male hormones (Testesterone, FSH, and LH). The dose $90 \mathrm{mg} / \mathrm{kg}$ showed great improvement in fertility. Thus, it seems that dose is considered as the effective dose However, further study is required for detecting the effects of aqueous extract on fertility dysfunction of male diabetic rats as well as isolation and identification of active constituents from this plant which may bring a dynamic change in the modern world.

\section{Acknowledgement}

The Authors would like to thank Al-Muthanna University, and University of Thi-Qar Republic of Iraq for financial support. The Authors would like to thank botanical Prof. Dr. Taha Yaseen Mhoder Al-Edany (Plant Taxonomy and Ecology, College of Agriculture, University of Basrah, Iraq) for the identification.

\section{Competing interests}

The authors declare that they have no competing interests.

\section{Ethical Committee}

This work was approved by Al-Muthanna University Ethical Committee.

\section{Authors' contributions}

All authors participated in the conception and design of the study, collected and analyzed the data, read and reviewed the final manuscript.

\section{References}

1. Shaw JE, Sicree RA, Zimmet PZ. Global estimates of the prevalence of diabetes for 2010 and 2030. Diab. Res. Clinic. Pra 2010; 87 (1): 4-14. https://doi.org/10.1016/.jiabres.2009.10.007

2. Aksu I, Baykara B, M.Kiray et al. Serum IGF-1 levels correlate negatively to liver damage in diabetic rats, Bio. Histochem 2013; 88: 194-201. https://doi.org/10.3109/10520295.2012.758311

3. Uysal N, Yalaz G, Acikgoz O, Gonenc S, Kayatekin BM. Effect of L-carnitine on diabetogenic action of streptozotocin in rats, Neuroe. Let 2005; 26(4): 419-422.

4. Amaral S, Oliveira PJ, Santos JR. Bentham Science Publishers Ltd, 2008; 4: 46-54. https://doi.org/10.2174/157339908783502398

5. Oksanen A. Testicular lesions of streptozotocin diabetic rats, Horm. Res 1975; 6(3): 138-144. https://doi.org/10.1159/000178671 
6. Sexton WJ, Jarow JP. Effect of diabetes mellitus upon male reproductive function, Urology 1997; 49(4): 508-513.

https://doi.org/10.1016/S0090-4295(96)00573-0

7. Guneli E, Tugyan K, Ozturk H, Gumustekin M, Cilaker S, Uysal N. Effect of melatonin on testicular damage in streptozotocin-induced diabetes rats, Euro. Sur. Res 2008; 40(4): 354-360. https://doi.org/10.1159/000118032

8. Jafar LM, Mahanem MN. Effects of aqueous extract Lunasia amara blanco on sperm quality, fertility and sexual behaviour of male rats Sains Malaysiana 2009; 38(5):793-797.

9. Amaral S, Oliveira PJ, Santos JR. Profertility and antidiabetic properties of Gynura procumbens on streptozotocin induced male rats, Bentham Science Publishers Ltd, 2008; 4: 46-54.

10. Meamar M, Zribi N, Cambi M, et al. Sperm DNA fragmentation induced by cryopreservation: new insights and effect of a natural extract from Opuntiaficus indica. Fertil. Steril 2012; 98(2): 326-

333. https://doi.org/10.1016/i.fertnstert.2012.05.001

11. Chidrawar VR, Chitme HR, Patel KN, et al. Effects of Cynodondactylon on stressinduced infertility in male rats. J. Young Pharm 2011; 3(1): 26-35.

https://doi.org/10.4103/0975-1483.76416

12. Lopez LM, Grimes DA, Schulz KF. Nonhormonal Drugs for Contraception in Men: A systematic review. Obstet. Gynecol. Surv 2005; 60: 746-52. https://doi.org/10.1097/01.ogx.0000182905.71077.13

13. González EM, López El, González EM, Tena FJ. Plantas Medicinales del Estado de Durango y Zonas Aledañas, CIIDIR Durango. IPN. México, D.F 2004: 41.

14. Ugulu S, Baslar Y, Dogan H. The determination of color intensity of Rubbia tinctorum and Chrozophora tinctoria distributed in Western Anatolia. XI Anniversary Scientific Conference Special Edition/on-Line 120 Years of Academic Education, In Biology 45 Years Faculty of Biology. Bio. Bio 2009; 410-413. https://doi.org/10.1080/13102818.2009.10818451

15. Başlar S, Mert HH. Studies on the ecology of Chrozophora tinctoria L. and Rubia tinctorum L. in Western Anatolia, Turk J. Bot 1999; 23: 33-44.

16. Mohamed KS. Phenylpropanoid glucosides from Chrozophora obliqua. Phytochemistry 2001; 58: 615- 618. https://doi.org/10.1016/S0031-9422(01)00262-X

17. Kodati DR, Burra S, Kumar GP. Evaluation of wound healing activity of methanolic root extract of Plumbago zeylanica L. in wistar albino rats, Asian Plant Sci. Res 2011; 1(2): 26-34.

18. Organisation for Economic and Cultural Development. Guidelines for Testing Chemicals, Acute Oral Toxicit up and down Procedure 2001; 425: 1-26.

19. Villano D, Fernandez-Pachon MS, Moya ML, Troncoso AM, Garcia-Parrilla MC. Radical scavenging ability of poly phnolic compounds towards DPPH free radical, Talanta 2007; 71(1): 230-235. https://doi.org/10.1016/j.talanta.2006.03.050

20. Konaté K, Bassolé IHN, Hilou A, et al. Toxicity assessment and analgesic activity investigation of aqueous acetone extracts of Sida acuta Burn f. and Sida cordifolia L.(Malvaceae), medicinal 
plants of Burkina Faso, BMC Complement Altern Med 2012; 12: 120.

https://doi.org/10.1186/1472-6882-12-120

21. WHO. Laboratory manual for the examination of human semen and sperm - cervical mucus interaction. Third Edition. Cambridge University press, 1992.

22. Auda MA, Saoudi MH. Anti-diabetic activity and hepatoprotective effect of Chrozophora tinctoria

(L.) Rafin leaves aqueous extract in STZ induced diabetic rats model. American Journal of BioMedicine 2019; 7(12): 51-57.

https://doi.org/10.18081/2333-5106/018-12/755-775

23. Navarro-Cassado L, Juncos-Tobarra MA, Chafer-Rudilla M, Iniguez de Onzono L, BlazquezCabrera JA. Effect of experimental diabetes and STZ on male fertility capacity. Study in rats., J. Androl 2010; 108: 007260.

https://doi.org/10.2164/iandrol.108.007260

24. Jackson FL, Hutson JC. Altered responses to androgen in diabetic male rats. Diabetes 1984; 33 : 819-824.

https://doi.org/10.2337/diab.33.9.819

25. Pitteloud N, Hardin M, Dwyer AA, et al. Increasing insulin resistance is associated with a decrease in Leydig cell testosterone secretion in men. J. Clin. Endocrinol. Metab 2005; 90: 26362641.

https://doi.org/10.1210/jc.2004-2190

26. Oksanen A. Testicular lesions of streptozotocin diabetic rats, Horm. Res 1975; 6: 138-144. https://doi.org/10.1159/000178671

27. Cai L, Chen S, Evans T, Xi Deng D, Mukherjee K, Chakrabarti S. Apoptotic germ-cell death and testicular damage in experimental diabetes: prevention by endothelin antagonism, Urol. Res 2000; 28: 342-347. https://doi.org/10.1007/s002400000134

28. Hutson JC, Stocco DM, Campbell GT, Wagoner J. Sertoli cell function in diabetic, insulin treated diabetic, and semi starved rats, Diabetes 1983; 32: 112-116.

https://doi.org/10.2337/diabetes.32.2.112

29. Sudha S, Valli G, Julie PM, Arunakaran J, Govindarajulu P, Balasu-Bramanian K. Influence of streptozotocin-induced diabetes and insulin treatment on the pituitary-testicular axis during sexual maturation in rat, Endocrinol. Diabetes 2009; 107: 14-20. https://doi.org/10.1055/s-0032-1329210

30. Khaki A, Nouri M, Fathiazad F, et al. Protective effect of quercetin on spermatogenesis in streptozotocin-induced diabetic rat. J. Med. Plan 2009; 8: 57-64.

31. La Vignera S, Condorelli R, Vicari E, D'Agata R, Calogero A. Diabetes mellitus and sperm parameters, J. Androl 2012; 33(2): 145-53. https://doi.org/10.2164/jandrol.111.013193

32. Shalaby MA, Mouneir SM. Effect of Zingiber officinale roots and Cinnamon zeylanicum bark on fertility of male diabetic rats. Global Veterinaria 2010; 5(6): 341-347. 
33. Bustos-Obregón E, González-Hormazabal P. Effect of a single dose of malathion on spermatogenesis in mice. Asian J. Androl 2003; 5: 105-107.

34. Malekinegad H, Mirzakhani N, Razi M, et al. Protective effects of melatonin and Glycyrrhiza glabra extract on ochratoxin A-induced detrimental impact on testes in mature male rats, Hum.

Exp. Toxicol 2010; 29: 110-123.

https://doi.org/10.1177/0960327110368416

35. Shalaby MA, Mouneir SM. Effect of Zingiber officinale roots and Cinnamon zeylanicum bark on fertility of male diabetic rats. Global Veterinaria 2010; 5(6): 341-347.

36. Shahreari S, Khaki A, Ahmadi-Ashtiani H, Rezazadeh S, Hajiaghaei R. Effects of Danae racemosa on testosterone hormone in experimental diabetic rats. J. Medici. Plants 2010; 9(35): 114-119.

37. Al-Joubori MAH. Histological and cytological effects of some plants extracts on hyperglycemic male rats. Ph.D Thesis. University of Babylon, 2012, Iraq.

38. Dutta $\mathrm{H}$, Meijer $\mathrm{H}$. Sublethal effects of diazinon on the structure of the testis of bluegill, Lepomis macrochirus: a microscopic analysis, Environ. Pollut 2003; 125: 355-360.

https://doi.org/10.1016/S0269-7491(03)00123-4

39. Alves MG, Martins AD, Cavaco JE, Socorro S, Oliveira PF. Diabetes, insulin-mediated glucose metabolism and Sertoli/blood-testis barrier function, Tissue Barriers 2013; 1(2): 1-10.

https://doi.org/10.4161/tisb.23992

\section{American Journal of BioMedicine}

Journal Abbreviation: AJBM

ISSN: 2333-5106 (Online)

DOI: 10.18081/issn.2333-5106

Email: editor@ajbm.net

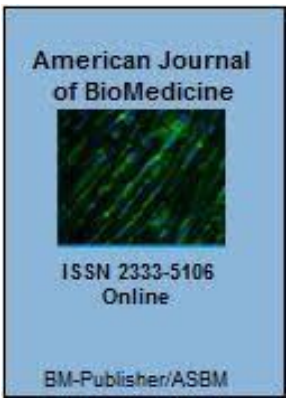

